\title{
An Analysis of Chinese Foreign Direct Investment (FDI) in Sub-Saharan Africa: A Particular Focus on Ethiopia
}

\author{
Dawit Tadesse $^{1}$
}

\begin{abstract}
This study offers an assessment of Chinese FDI in Sub-Saharan Africa with a particular focus on Ethiopia. The research method employed in this study has both qualitative and quantitative features. The findings of the study are presumed to be of paramount importance by inducting policy direction for policy makers in sub-Saharan Africa regarding Chinese investment in the region. The findings demonstrated some $90 \%$ of China (Sino) - sub-Saharan African trade is based around natural resources: oil, ores and minerals (MaryFrançoise Renard, 2011). Of course, China has certainly been contributing to sub-Saharan Africa's economic growth, both in terms of trade and building of infrastructure. However, the Chinese exports of natural resources by themselves do not help sub-Saharan Africa because oil and mining are not labor intensive industries which even if natural resources may create economic growth in figures, does not necessarily translate into widespread job creations. In addition, large oil and mineral reserves can also distort the local currency, pushing up prices of other exports, such as agricultural and manufacturing products making them much harder to sell overseas.

What makes the Chinese FDI unique in Ethiopia is almost $60 \%$ of these investments are concentrated in the manufacturing sector and infrastructural development, which is different from what happened in other African countries where the Chinese FDI is pretty much resource seeking (Alemayehu Geda and Atnafu G. Meskel, 2009). There are concerns related to China FDI in Ethiopia such as the dumping of low quality Chinese goods in Ethiopian markets, Chinese manufacture poor employees' safety practices, the Chinese imports negative impact on domestic industries and Chinese investors' involvements in corruption and other trade frauds. In conclusion, to realize the major benefits by reducing risks associated with this Chinese FDI in sub-Saharan Africa, countries must have appropriate policies and strategies including strong institutions arrangement.
\end{abstract}

Keywords: FDI, Sub-Saharan Africa, Chinese FDI in Sub-Saharan Africa, China, Ethiopia

DOI: http://dx.doi.org/10.4314/ejbe.v4i2.1

${ }^{1}$ Change Management Team Leader In Ethiopian Revenues and Customs Authority and Lecturer in St. Mary's University, Department of Accounting, Address: Pox. 130, Addis Ababa, Ethiopia ,E:mail:dawittadesse9053@yahoo.com , Mobile Phone: 251911109648 


\section{Introduction}

China's rapid economic growth has been remarkable. Currently, China's economy has surpassed Italy, Japan, Germany, France, and the United Kingdom to become the world's second largest economy after the United States. In the mean time, few analysts are even predicting that the Chinese economy will be larger than that of the United States in about 20 years (Deborah Brautigam, 2009).

Following this extraordinary economic growth of China, today the Chinese appetite for African's energy, natural resources and market for cheap Chinese products is dramatically increasing. China-Africa trade has increased radically in the past decade and in 2009 this trade figure reached close to $\$ 100$ billion and in 2011 it reached more than 120 billion dollars (Deborah Brautigam, 2009). Now, China is on track to become the African continent's largest partner, outpacing Britain and the United States.

The impact of China on African economies particularly in sub-Saharan Africa has been diverse, depending in part on the sectoral composition of each country's production (Mary-Françoise Renard, 2011). Ethiopia is no exception to this impact.

Chinese Foreign Direct Investment (FDI) into Sub-Saharan Africa (SSA) has grown rapidly in recent years. Official estimates of China's FDI flows to SSA are contradictory and almost certainly understate their true significance (John Whalley and Aaron Weisbrod, 2011).

China imports mainly oil, coal, gold and raw material and exports huge consumer goods to SSA countries. Generally there is an understanding that many African consumers benefited from the cheap Chinese goods and China's imports of commodities which are pushing up the prices of SSA exports thereby enhancing the earnings of the exporters in African countries (Ali Zafar, 2007). In addition, Chinese aid and investment in infrastructure are bringing desperately needed capital to the continent. In this regard, for example, in the last seven years China has become an important trading partner for Ethiopia accounting about $15 \%$ of its trade which was none before 2005 (Alemayehu Geda and Atnafu G. Meskel,2010).

However, China's emergence as a major player in sub-Saharan Africa trade, investment, and aid has led to many concerns. For example, even if a strong Chinese demand for oil is enhancing the earnings of the exporters in African 
countries, its exports of low-cost textiles, while benefiting African consumers, is threatening to displace local production. In addition, because of the huge oil exploration and import of China, many African countries are facing challenges in good governance and macroeconomic management because of the potential Dutch disease implications of commodity booms. This means, in the Dutch disease scenario, the natural resources boom will lead to an increase in national income, but will paradoxically lead to deindustrialization (and "deagriculturalization") and has an adverse effect on the competitiveness of the country's other exports (John Whalley and Aaron Weisbrod, 2011). In line with this, as Joseph Stieglitz (2012) puts it,

"China's investment on infrastructures in Africa including roads, railroads, and ports has been built with one goal in mind: getting the resources out of the country at as low a price as possible, with no effort to process the resources in the country, let alone to develop local industries based on them. Real development requires exploring all possible linkages: training local workers, developing small and medium size enterprises to provide inputs for mining operations and oil and gas companies, domestic processing, and integrating the natural resources into the country's economic structure".

In addition, critics comment that most of China's companies' investments in Africa do not give serious considerations for environmental and ecological conditions. Pertinent to Ethiopia's case, relation to the growing China trade, investment, and aid has led to many concerns such as:

- threatening to displace local production

- Poor quality Chinese products

- Illegal trading movement of Chinese investors: corruption, illegal money transfer, working without getting official licenses

In this regard the purpose of this study is to offer a broader evaluation of Chinese FDI in sub-Saharan Africa, with a particular focus on the costs and benefits of SINO FDI in Ethiopia. In line with this, the Figure 1.1 below illustrates the study framework of this paper and how the Sub-Saharan Countries including Ethiopia can maximize benefits from Chinese FDI by developing clear polices and strategies on investment. 
Figure 1.1 Paradigm of China's FDI in Sub-Saharan Africa

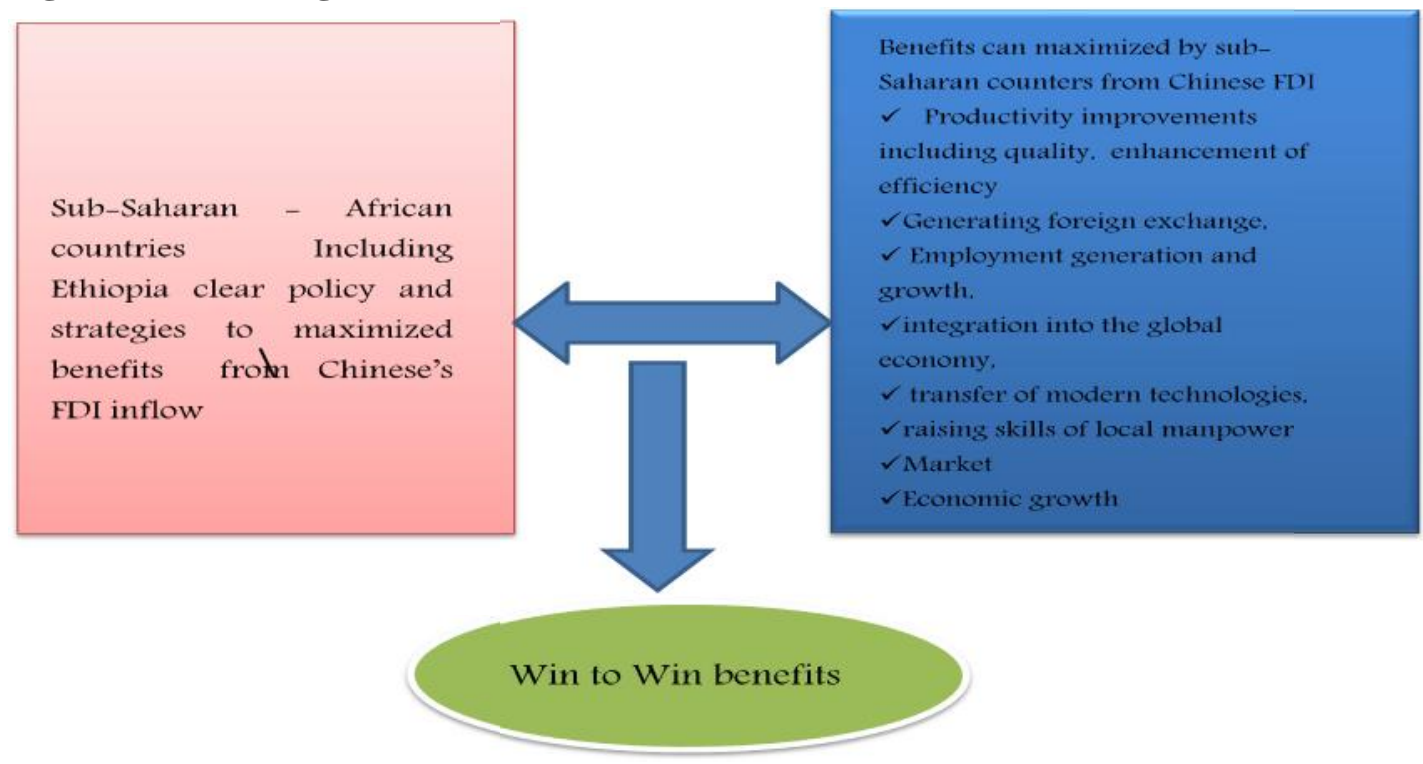

Source: Author view

This paper is organized into four sections. The first section provides introduction. The second section endows with literature review. The third section deals with methodology. Section four presents broader evaluation of Chinese FDI in Sub-Saharan Africa and section five focuses on evaluation of Chinese FDI in Ethiopia and section six presents conclusions and policy recommendations.

\section{Literature Review}

In theories the most important benefits of foreign direct investment (FDI) for every country including developed and developing is a driver of employment, technological progress, productivity improvements, and ultimately economic growth. In addition FDI benefits the development process of developing countries in terms of generating foreign exchange, upgrading investment, and boosting tax revenue. Specifically for Africa development, FDI inflow can have huge importance in relation to supplementing domestic savings, employment generation and growth, integration into the global economy, 
transfer of modern technologies, enhancement of efficiency, and raising skills of local manpower.

In this regard, even if Africa has never been a major recipient of FDI inflows, currently because of the extraordinary economic growth of China, Chinese FDI inflow in Africa in general and in sub-Saharan countries in particular including Ethiopia has dramatically increased. It is a widely held view that, China's emergence as a major player in sub-Saharan Africa, including Ethiopia, in trade, investment, and aid has led to many concerns.

One of the major concerns is if Chinese FDI inflow is not managed by clear policies and strategies, it will have huge negative impacts on the domestic economy. These impacts could be environmental and economic damages because the ambition of foreign companies to earn cheaper resources can reduce employment by dismissing local workers and by crowding out local businesses. If domestic market integration is insufficient, technology transfers will be difficult; positive capital flows often turn into negative if investors use cheap local raw materials and resources and sell expensive final goods (Asta Žilinsk , 2010).

China's relation with African countries is a part of its global economic strategy that is geared towards obtaining energy resources, searching for new market and investment opportunity. In addition there are also political considerations for which African countries were credited by China for their being instrumental in preventing Chinese Taiwan from obtaining a seat at the United Nations Security Council (Mary-Françoise Renard, 2011).

\section{Research Methodology}

The problem area that is studied in this paper is wide and complex. This indicates that a wide range of methods may be relevant. To identify and understand very clearly the Chinese foreign direct investment (FDI) in Sub Saharan Africa: a particular focus on Ethiopia, it needs multi-method approach. In order to select appropriate research methods for this study, the study explored and reviewed different philosophical schools of research thoughts which are very important to select and shape appropriate methodology for any kind of research.

This study relied on both primary and secondary data obtained from various sources. In addition, to shed a light on Chinese FDI in Sub-Saharan Africa, 
with a special focus on the costs and benefits of Sino FDI in Ethiopia, both descriptive and analytical methods are employed as data analyses method of the research. The major purpose of descriptive research is the description of the state of affairs as it exists at present. On the other hand, an analytical method is applied to use facts and information already available and to analyse these to make a critical evaluation of the undertaking on a sampling base in different categories and approaches of research.

Considering lack of available data and China's unwillingness to be transparent about their activities and intentions in Sub-Saharan Africa including Ethiopia, empirical investigation is very important. Because of this reason, the appropriate research strategy for this study is mutually reinforcing 'triangulation' method which is presented in figure 3 below. The three key research elements of this approach are secondary research, survey/questionnaires, and interviews.

\section{Figure 3: Triangulation Research Methodology Model}

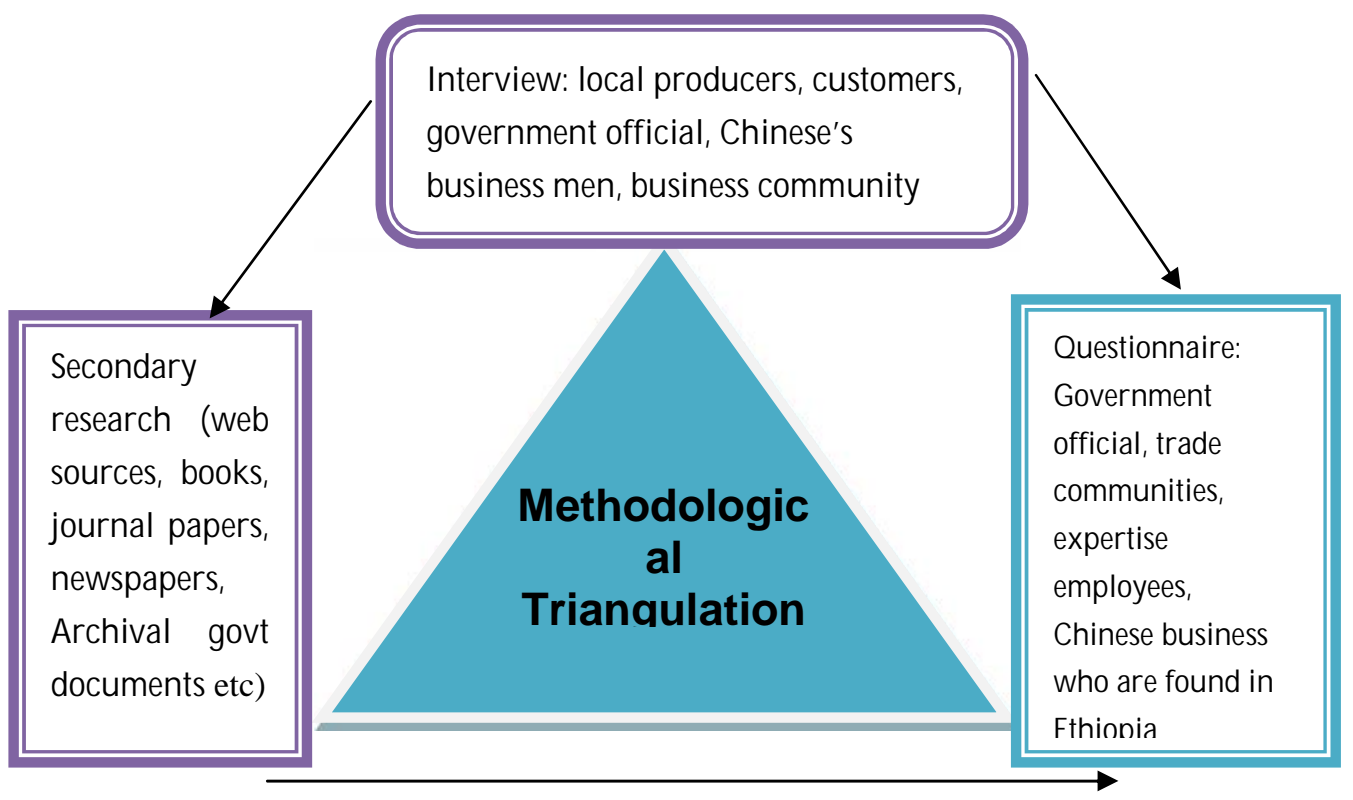

\subsection{Secondary Research}

To see the key features and patterns of Chinese FDI in Sub-Saharan Countries, this study used secondary data including the documentation produced by 
National Governments, National public service organizations with special emphasis on trade and investment, regional institutions, international bodies (such as: IMF, World bank, Africa Development Bank) annual report issues by Chinese government investment in Africa, commercial enterprises, and the media including journals.

In addition, to evaluate Chinese FDI benefits and the underlying disadvantages to Ethiopia cases particularly, secondary data were collected from the key Ethiopian government offices, such as; Ethiopian Investment Authority, Ethiopian Revenues and Customs Authority, Ethiopian Government official reports, Ethiopian Conformity Assessment Enterprise, Ethiopian Ethics and Anti- corruption Commission, Ethiopian Economic Association, Ethiopian Ministry of Trade, Ministry of Defense and Ethiopian Roads Authority.

Web-sites:

www.imf.org.

wwW.worldbank.org

www.afdb.org

www.un.org

english.mofcom.gov.cn/statistic/statistic.html

ec.europa.eu/trade/creating-opportunities/bilateral-relations/regions/

www.comesatradehub.com

http://aigaforum.com

www.googel.com

wWw.aercafrica.org

www.wto.org

www. unctad.org/en/Pages/Statistics.aspx/

\subsection{Questionnaire}

The study used primary data method acquisition with structured questionnaires administered at Ethiopian Investment Authority, Ethiopian Revenues and Customs Authority, experts, Ethiopian Ministry of Trade, Ministry of Defense, Ethiopian Conformity Assessment Enterprise, Ministry of Industry, Ethiopian Road Authority, policy makers, selected Textile and Leather factories which are owned by Ethiopians. The questionnaires were designed in twelve major areas such as: Chinese FDI inflow, capacity building, technology transfer, 
operational costs, employment, domestic producers (deindustrialization), foreign exchange, loan, productive, market, quality, strategy and policy resource, corruption, environment and aid.

The questionnaires were e- mailed to the above bodies and delivered to them in their places. These respondents represented about $70 \%$ of total population working directly with Chinese FDI inflow in Ethiopia. Their feedback is very important to understand costs and benefits of Sino FDI in Ethiopia

\subsection{Interview}

The study used interview as primary data method and administered it with: local producers specially Textile and Leather factories owners, customers, government official working for Ethiopian Quality and Standard Authority, Ethiopian Ministry of Trade, Ethiopian Investment Authority, Ethiopian Ethics and Anti -corruption Commission and Chinese business men.

\subsection{Local producers}

Field works were conducted on Ethiopian local factory owners specially those producing shoe and textile products. As most studies indicate, the Chinese exports of low-cost textiles and leather products in Africa including Ethiopia, while benefiting African consumers, are threatening to displace local production. 
Table 3.4: Footwear \& Leather Products Manufacturers

The field work was conducted with footwear and leather products manufacturers' specially producing footwear and leather

\begin{tabular}{|c|c|c|c|c|}
\hline No. & Company & Name & Title & Company Name Address \\
\hline $\mathbf{1}$ & $\begin{array}{l}\text { Genuine } \\
\text { Leather Crafts } \\
\text { PLC }\end{array}$ & $\begin{array}{l}\text { Ato Teshome } \\
\text { Kebede }\end{array}$ & Owner & $\begin{array}{l}\text { Tel. } 251115531894 \\
\text { Mob. } 251920803791 \\
\text { Fax 251 } 115518841 \\
\text { e-mail: glc@ethionet.et } \\
\text { P.O.Box } 2218 \text { Addis Ababa, Ethiopia }\end{array}$ \\
\hline 2 & $\begin{array}{ll}\text { Anbessa } & \text { Shoe } \\
\text { S/C } & \end{array}$ & $\begin{array}{l}\text { The person not } \\
\text { interested to } \\
\text { mention his } \\
\text { name }\end{array}$ & $\begin{array}{l}\text { Marketing } \\
\text { Department }\end{array}$ & $\begin{array}{l}\text { Tel. 251-011-2754269 } \\
\text { Mob.251-091- 1205229 } \\
\text { Fax: 251-011-2756335 } \\
\text { e-mail: anshoeco@ethionet.et } \\
\text { P.O.Box: 1641 Addis Ababa, Ethiopia }\end{array}$ \\
\hline 3 & $\begin{array}{l}\text { Ethio-Leather } \\
\text { Industry PLC } \\
\text { (ELICO) }\end{array}$ & - & $\begin{array}{l}\text { Marketing } \\
\text { Department }\end{array}$ & $\begin{array}{l}\text { Tel. } 2510115513691 \\
\text { Fax: } 2510115512822 \\
\text { e-mail: eth.tannery@ethionet.et } \\
\text { P. O. Box } 5628 \text { Addis Ababa, Ethiopia }\end{array}$ \\
\hline 4 & $\begin{array}{l}\text { Jamaica Shoe } \\
\text { Factory }\end{array}$ & $\begin{array}{l}\text { Ato Tesfaye } \\
\text { Teshome }\end{array}$ & owner & $\begin{array}{l}\text { Tel. 251-011-1564280 } \\
\text { Mob. 251-091-1204524 } \\
\text { Fax: 251-011-1553114 } \\
\text { e-mail: Okjamaica@ethionet.et } \\
\text { P.O.Box: 26430 Addis Ababa, Ethiopia }\end{array}$ \\
\hline 5 & $\begin{array}{l}\text { Kangaroo Shoe } \\
\text { Factory }\end{array}$ & Ato Yosfe & $\begin{array}{l}\text { Marketing } \\
\text { Department }\end{array}$ & $\begin{array}{l}\text { Tel. } 2510114421451 / 52 \\
\text { Mob. 091/1212801 } \\
\text { Fax: } 2510114421454 \\
\text { e-mail: Batutan@ hotmail.com } \\
\text { P. O. Box } 1273 \text { Addis Ababa, Ethiopia }\end{array}$ \\
\hline 6 & $\begin{array}{l}\text { Peacock shoe } \\
\text { Factory }\end{array}$ & - & $\begin{array}{l}\text { Marketing } \\
\text { Department }\end{array}$ & $\begin{array}{l}\text { Tel. 251-011-2756443 } \\
\text { Fax:251-011-2752455 } \\
\text { e-mail: dire@ethionet.et }\end{array}$ \\
\hline 7 & $\begin{array}{ll}\text { Ramsy } & \text { Shoe } \\
\text { Factory } & \end{array}$ & - & $\begin{array}{l}\text { Marketing } \\
\text { Department }\end{array}$ & $\begin{array}{l}\text { Tel. 251-011-2753728 } \\
\text { Fax: 251-011-1550530 } \\
\text { e-mail: Ramsay@ yahoo.com } \\
\text { P.O.Box: 182807 Addis Ababa, } \\
\text { Ethiopia }\end{array}$ \\
\hline 8 & $\begin{array}{l}\text { Tikur Abaay } \\
\text { Shoe S/C }\end{array}$ & W/r Yiete sisay & $\begin{array}{l}\text { Marketing } \\
\text { Manager }\end{array}$ & $\begin{array}{l}\text { Tel. 251-011-2701803 } \\
\text { Mob. 251-091-1205527 } \\
\text { Fax: 251-011-2704050 } \\
\text { e-mail: Tikurabay@ ethionet.et } \\
\text { P.O.Box: 802 Addis Ababa, Ethiopia }\end{array}$ \\
\hline
\end{tabular}

EJBE Vol. 4 No. 2/2014 
Analysis of Chinese FDI in Sub-Saharan Africa

\section{Table 3. 5: Textile \& Garment Manufacturers}

The field work was conducted with textile $\&$ garment manufacturers specially producing shoe and textiles.

\begin{tabular}{|c|c|c|c|c|}
\hline No. & Company & Name & Title & Company Name Address \\
\hline 1 & $\begin{array}{l}\text { Awassa Textile } \\
\text { Share Company }\end{array}$ & $\begin{array}{c}\text { Etenshe } \\
\text { wabshow }\end{array}$ & $\begin{array}{l}\text { Marketing } \\
\text { Manager }\end{array}$ & $\begin{array}{l}\text { Fax. Q11-5-514-984/5-514984 } \\
\text { Tel. 011-5-51-89-00 } \\
\text { E-mail: habibnarin@ awassa } \\
\text { textile com. }\end{array}$ \\
\hline 2 & $\begin{array}{l}\text { Ambassador } \\
\text { Garment }\end{array}$ & - & $\begin{array}{c}\text { Marketing } \\
\text { Department }\end{array}$ & $\begin{array}{l}\text { Fax. 011-6-461-442 } \\
\text { Tel. 0116461427 } \\
\text { E-mail: amb garment @ ethionet }\end{array}$ \\
\hline 3 & $\begin{array}{l}\text { Nazerette } \\
\text { Garment }\end{array}$ & $\begin{array}{l}\text { Lemanew } \\
\text { Mkurya }\end{array}$ & Owner & $\begin{array}{l}\text { Fax. 022-1-111-733/0114405279 } \\
\text { Tel. 0221113361/0911207836 } \\
\text { E-mail:----- }\end{array}$ \\
\hline 4 & Mulate Garment & Abera Mulate & Owner & $\begin{array}{l}\text { Fax. 011-4-403-614 } \\
\text { Tel. 011-4-40-36- } \\
\text { 15/0911406833 } \\
\text { E-mail: mulata@ethhionet.et }\end{array}$ \\
\hline 5 & $\begin{array}{l}\text { Adye-Ababa } \\
\text { Yarm Factory }\end{array}$ & - & $\begin{array}{c}\text { Marketing } \\
\text { Department }\end{array}$ & $\begin{array}{l}\text { Fax. Q11-5-514-42Q/44Q5-12Q } \\
\text { Tel. 011-4-42-06-18/ 0911- } \\
\text { 245816 } \\
\text { E-mail: }\end{array}$ \\
\hline 6 & $\begin{array}{ll}\text { Akaki } & \text { Garment } \\
\text { Factory } & \end{array}$ & - & $\begin{array}{l}\text { Marketing } \\
\text { Department }\end{array}$ & $\begin{array}{l}\text { Fax. Q11-4-34Q-222 } \\
\text { Tel. 011-4-34-01-54 } \\
\text { E-mail: }\end{array}$ \\
\hline
\end{tabular}

\subsection{Customers}

The study used interview as primary data acquisition method and administered it to 300 consumers of Chinese products who were selected using random sampling method.

\subsection{Ethiopian Employees who are currently working for Chinese Firms in Ethiopia}

The study used primary data acquisition method of self administered questionnaire on with 400 Ethiopian employees out of 2500 working for 
Chinese Companies in Eastern Industrial zone in Dukem, in Oromia Regional State in Ethiopia.

\subsection{Government official}

The field work was conducted on Government officials who are working in investment and trade area directly and indirectly.

\section{Table: 3. 8 Government officials}

\begin{tabular}{|c|c|c|c|}
\hline No. & Organization & Name & Title \\
\hline 1 & $\begin{array}{l}\text { Ethiopian Conformity } \\
\text { Assessment Enterprise }\end{array}$ & $\begin{array}{l}\text { Ato Solomon } \\
\text { Muluberhan }\end{array}$ & $\begin{array}{l}\text { Branch Coordinator and Customer } \\
\text { Service Expert: } \\
\text { Tel:251-912017976 }\end{array}$ \\
\hline 2 & $\begin{array}{l}\text { Ethiopian Investment } \\
\text { Authority }\end{array}$ & Ato Nigusay Girm & $\begin{array}{l}\text { Planning Director } \\
\text { Tel:251-911459497 }\end{array}$ \\
\hline 3 & $\begin{array}{l}\text { Ethiopian Anti - } \\
\text { corruption } \\
\text { Commission }\end{array}$ & Ato.Geberu Gebyehu & $\begin{array}{l}\begin{array}{l}\text { Director of Investigation } \\
\text { Criminal }\end{array} \\
\text { Tel:0115529100/Ex.231 } \\
\end{array}$ \\
\hline 4 & $\begin{array}{l}\text { Ethiopian Ministry of } \\
\text { Trade }\end{array}$ & Ato Yosef Alemu & $\begin{array}{l}\text { Licenses Registration Team Leader } \\
\text { Tel:251-1-115-113622 }\end{array}$ \\
\hline 5 & $\begin{array}{l}\text { Ethiopian Ministry of } \\
\text { Industry }\end{array}$ & Ato Fikdu Ababe & $\begin{array}{l}\text { Planning Director } \\
\text { Tel:251-1-115- } 507210\end{array}$ \\
\hline 6 & $\begin{array}{l}\text { Ethiopian } \\
\text { Authority }\end{array}$ & $\begin{array}{l}\text { AtoTadesse Brhanu } \\
\text { G/Kirstoes } \\
\text { AtoGedefaw } \\
\text { Assmamaw }\end{array}$ & $\begin{array}{l}\text { Road Quality Director :Tel 251-1- } \\
\text { 115-153685 } \\
\text { Human Resource Team leader } \\
\text { Tel:251-911468574 } \\
\text { Easter Branch Director :Tel.251-1- } \\
\text { 115155494 }\end{array}$ \\
\hline
\end{tabular}

\subsection{Chinese Firms}

The study used interview as primary data acquisition method and administered for 10 Chinese companies officials who are working for Chinese firms working in Ethiopia who were selected using random sampling method. These business men were contacted at Ethiopian Revenues and Customs Authority head office in Addis Ababa. 


\section{Analysis : Origins, Trends and Nature of Chinese FDI in Sub- Saharan Africa \\ 4.1 Origins of Chinese FDI in Sub-Saharan Africa}

Historically, trade relations between China and Africa date back to the first Han emperors of the Second Century B.C., This relationship started to strengthen at the Bandung Conference following the establishment of the Peoples Republic of China in 1949. Currently, following the opening up of China's economy initiated by Deng Xiaoping, China's relationship with Africa is no longer dominated by ideological concerns, except for the sensitive issue of Chinese Taiwan. Rather this relationship is based on the official principles of engagement, including equality among partners, mutual benefit, and respect for sovereignty, use of interest-free grants and loans, beneficiary capacity building, compliance with obligations and provision of equipment made in China (Deborah Brautigam,2009).

Currently the Chinese FDI in sub-Saharan African countries especially in those resource rich countries has shown substantial growth. More recently, China's growing dependence on energy has led Africa gain prominence on China's agenda. Trade between China and Africa has increased tremendously. At present, there are an estimated more than 800 Chinese corporations doing business in Africa, most of which are private companies investing in the infrastructure, energy and banking sectors ( Deborah Brautigam , 2009).

Many critics say origins of Chinese FDI in Sub-Saharan Africa is coming from the Chinese strategy that is entirely self-promotional, aimed at maintaining access to sub-Saharan Africa's precious resources. In this regard, for example, some $90 \%$ of Sino- sub-Saharan African trade is based around natural resources: oil, ores and minerals. Over the last decade, China has built a network of trade, aid, and investment links with close to 50 African countries, and there has been a rush to buy up concessions of Africa's natural resources (Mary-Françoise Renard, 2011).

Currently China's trade with Africa is highly concentrated on resource rich countries. Among these countries listed in table 4.1 below, $67 \%$ of them are sub-Saharan African countries, $60 \%$ Chinese exports are destined for only six countries and $70 \%$ of Chinese imports originate from four countries. These countries are resources rich countries.

EJBE Vol. 4 No. 2/2014

Page 194 
Analysis of Chinese FDI in Sub-Saharan Africa

Table 4.1: China's Trade with Africa

\begin{tabular}{|l|l|l|l|l|}
\hline NO. & $\begin{array}{l}\text { 60\% of Chinese exports } \\
\text { are destined for only six } \\
\text { countries }\end{array}$ & $\begin{array}{l}\text { Percentage } \\
\mathbf{( 1 0 0 \% )}\end{array}$ & $\begin{array}{l}\mathbf{7 0 \%} \text { of Chinese } \\
\text { imports } \\
\text { originate from } \\
\text { four countries }\end{array}$ & $\begin{array}{l}\text { Percentage } \\
\mathbf{( 1 0 0 \% )}\end{array}$ \\
\hline $\mathbf{1}$ & South Africa & $21 \%$ & Angola & $34 \%$ \\
\hline $\mathbf{2}$ & Egypt & $12 \%$ & south Africa & $20 \%$ \\
\hline $\mathbf{3}$ & Nigeria & $10 \%$ & Sudan & $11 \%$ \\
\hline $\mathbf{4}$ & Algeria & $7 \%$ & $\begin{array}{l}\text { Republic } \\
\text { Congo }\end{array}$ & $8 \%$ \\
\hline $\mathbf{5}$ & Morocco & $6 \%$ & & \\
\hline $\mathbf{6}$ & Benin & $5 \%$ & & \\
\hline
\end{tabular}

Sources: Mary-Françoise Renard (2011)

Of course, on the other hand, China has certainly been contributing to subSaharan Africa's economic growth, both in terms of trade and with building of infrastructure. Throughout Sub-Saharan Africa, Chinese companies are building vital infrastructure, including dams, ports, and roads, and are helping to renovate government offices and other buildings. In addition, Chinese firms have ventured into the light manufacturing and services sectors and entered into agro processing, apparel, and telecommunications. Moreover, consumers of sub-Saharan African countries are benefiting from the Chinese's low-cost motorcycles, electronic goods, and textile and shoes products. In line with this, China has bilateral trade and economic cooperation with many sub-Saharan African countries.

\subsection{Trends of Chinese FDI across sectors and Countries}

China has become the leading country in foreign direct investment in Africa. During the year 2011, trade between Africa and China increased a staggering $33 \%$ from the previous year to US \$166 billion. This included Chinese imports from Africa equaling US $\$ 93$ billion, consisting largely of mineral ores, petroleum, and agricultural products and Chinese exports to Africa totaling \$93 billion, consisting largely of manufactured goods. Outlining the rapidly expanding trade between the African continent and China, trade between these two areas of the world increased further by over $22 \%$ year-over-year to US $\$ 80.5$ billion during the first five months of the year 2012 (Deborah Brautigam, 2009). 
In this regard, Chinese Foreign Direct Investment (FDI) into Sub-Saharan Africa (SSA) has grown rapidly in recent years. The large China FDI in SSA is predominantly investing in resource extraction and infrastructure. In addition, the key sectors where Chinese are currently investing in sub-Saharan countries are Gas, Mining, Agriculture, Services, Retail Physical, infrastructure and Manufacturing.

Table 4.2 below summarizes the key sectors where Chinese investment is located in sub-Saharan African countries. This table identified the three groups of economies - those in which Chinese FDI plays a relatively significant role, relatively moderate role, and those in which its significance is low. 
Analysis of Chinese FDI in Sub-Saharan Africa

Table 4.2: Chinese FDI in key sectors in 20 SSA Economies

\begin{tabular}{|c|c|c|c|c|c|c|c|}
\hline Country & Gas /Oil & Mining & Agriculture & Services & Retail & $\begin{array}{l}\text { Physical } \\
\text { infrastructure }\end{array}$ & Manufacturing \\
\hline \multicolumn{8}{|c|}{ Economies where Chinese FDI plays a significant role } \\
\hline Angola & & & & Telecoms & Small traders & \multicolumn{2}{|l|}{$\begin{array}{l}\text { Construction, } \\
\text { Infrastructure }\end{array}$} \\
\hline Ethiopia & & & & $\begin{array}{l}\text { Telecoms, } \\
\text { Electricity, } \\
\text { Water }\end{array}$ & Small traders & Construction & $\begin{array}{l}\text { Shoes/leather, } \\
\text { Garments }\end{array}$ \\
\hline Ghana & & & Poultry & & $\begin{array}{l}\text { Small } \\
\text { traders, } \\
\text { Import/ export }\end{array}$ & & $\begin{array}{l}\text { Garments, } \\
\text { Shoes/leather }\end{array}$ \\
\hline Madagascar & & & Sugar & $\begin{array}{l}\text { Telecoms, } \\
\text { Financial }\end{array}$ & $\begin{array}{l}\text { Small } \\
\text { traders, } \\
\text { Import/ export }\end{array}$ & & $\begin{array}{l}\text { Garments, general } \\
\text { spread }\end{array}$ \\
\hline Nigeria & & & & $\begin{array}{l}\text { Telecoms, } \\
\text { Technical } \\
\text { services }\end{array}$ & Small traders & $\begin{array}{l}\text { Construction, } \\
\text { infrastructure, }\end{array}$ & Agro-processing \\
\hline Mauritius & & & & & $\begin{array}{l}\text { Small } \\
\text { traders, } \\
\text { Import/ export }\end{array}$ & & $\begin{array}{l}\text { Textiles, Garments, } \\
\text { General spread }\end{array}$ \\
\hline Sudan & & & & & Small traders & & \\
\hline Zambia & & & Cotton & & & Construction & Agro-processing \\
\hline \multicolumn{8}{|c|}{ Economies where Chinese FDI plays a moderately significant role } \\
\hline $\begin{array}{l}\text { Congo - } \\
\text { Brazzaville }\end{array}$ & & & $\begin{array}{l}\text { Health, } \\
\text { Telecom }\end{array}$ & & $\begin{array}{l}\text { Energy, } \\
\text { Construct }\end{array}$ & & \\
\hline
\end{tabular}

EJBE Vol. 4 No. 2/2014 
Analysis of Chinese FDI in Sub-Saharan Africa

\begin{tabular}{|c|c|c|c|c|c|}
\hline Kenya & Coffee & & $\begin{array}{l}\text { Small } \\
\text { traders, } \\
\text { Import/export }\end{array}$ & & $\begin{array}{l}\text { Garments, } \\
\text { Shoes, General Spread }\end{array}$ \\
\hline Mali & Cotton & $\begin{array}{l}\text { Water, } \\
\text { Electricity }\end{array}$ & & $\begin{array}{l}\text { Construction, } \\
\text { Infrastructure }\end{array}$ & Food processing \\
\hline S. Africa & & Financial & Small traders & $\begin{array}{l}\text { Constructions, } \\
\text { infrastructure }\end{array}$ & $\begin{array}{l}\text { Electronic } \\
\text { Goods }\end{array}$ \\
\hline Uganda & Cotton & $\begin{array}{l}\text { Telecoms, } \\
\text { Electricity }\end{array}$ & Small traders & $\begin{array}{l}\text { Construction, } \\
\text { infrastructure }\end{array}$ & Agro-processing, General spread \\
\hline \multicolumn{6}{|c|}{ Economies where Chinese FDI plays a relatively insignificant role } \\
\hline Cameroon & $\begin{array}{l}\text { Rice, } \\
\text { Timber, } \\
\text { Fish }\end{array}$ & & Small traders & $\begin{array}{l}\text { Construction, } \\
\text { Infrastructure }\end{array}$ & \\
\hline \multicolumn{6}{|l|}{ Chad } \\
\hline \multicolumn{6}{|l|}{ Cote d'Ivoire } \\
\hline \multicolumn{6}{|l|}{ Gambia } \\
\hline \multicolumn{6}{|l|}{ Guinea } \\
\hline Namibia & & & Small traders & Construction & \\
\hline Tanzania & Cotton & & & Construction & \\
\hline
\end{tabular}

Sources: Raphael Kaplinsky and Mike Morris (2009) 
According to the above data, there are economies where Chinese oil-gas and mining investments are playing considerable role. In this regard, as it is mentioned in table 4.2 above, in Africa more than $60 \%$ of Chinese exports are destined for only six countries and $70 \%$ of Chinese imports originate from four countries.

On other hand, there are economies in which Chinese FDI is significantly low; such as Chad, Cote d'Ivoire, Gambia Guinea and Namibia. In agriculture, the primary sector of Chinese involvement is cotton, but only in Zambia it plays an important role in this sector. Chinese FDI in telecoms is significant all over the above mentioned 20 economies but these are significant notably in Ethiopian and Malian economies. In construction and infrastructure sectors, Chinese FDI plays an important role in the above almost all economies. Even if Chinese FDI in manufacturing is primarily in labour intensive activities - garments dominate but there are also small scale manufacturing enterprises investments which have a more substantial socioeconomic impact. These investments are widespread in almost every economy however they have no official statistics.

\subsection{Pattern of Chinese investment in Natural Resources in Sub-Saharan Africa}

China's economic ascendance over the past two decades has generated ripple effects in the world economy. Beijing's new target is to quadruple its economy again between 2000 and 2020 (Wenran Jiang, 2009). According to Petroleum Exporting Countries, China's oil demand will double by 2030. Currently, China alone is at present responsible for $30 \%$ of global oil demand growth $(\mathrm{C} h$ ris A 1 de n a n d A n a C ris ti n a A lve s, 2009). To achieve that goal, China must rely more and more on external energy supplies (Wenran Jiang, 2009). In this regard, China's search for natural resources to satisfy the demands of industrialization has forced it to turn its face to Sub-Saharan Africa.

Of course one of the major single most striking characters of China's ties with Africa is China's growing hunger for more and more energy and natural resources. China's fastest growing economy currently requires more energy. China's modernization is the result of a manufacturing structure that requires huge increases in energy consumption. With about 6 per cent of global GDP, 
China consumes $31 \%$ of the world's coal, $30 \%$ of iron, 27 per cent of steel, 40 $\%$ of cement, $20 \%$ of copper, $19 \%$ of aluminium and $10 \%$ of electricity (Ali Zafar, 2007).

Because of Chinese appetites for the African energy, natural resources, currently China's trade with Africa is highly concentrated on resources countries. This pattern of Chinese investment in the oil sector in sub-Saharan Africa is flowing not only in other established major oil producers such as Sudan and more recently in Nigeria, but also in smaller producing states (Gabon and Congo-Brazzaville) and new producers (Equatorial Guinea and Chad) (Chris A lden and A n a Cristin a A lves, 2009).

It is not surprising that currently Africa has turned into a major energy supplier to China in recent years. For example, in 2007, 72\% of China's total imports from Africa are crude oil, with non-primary commodities imports accounting for only 4\% (John Whalley and Aaron Weisbrod, 2011). One of the major benefits of Chinese companies importing oil and other natural resources from sub-Saharan Africa has contributed to an upward swing in prices, particularly for oil and metals from Africa, and has given a boost to real GDP in SubSaharan Africa (John Whalley and Aaron Weisbrod, 2011).

However, as noted above, the Chinese exports of natural resources by themselves do not help sub-Saharan Africa because oil and mining are not labor intensive industries, even if natural resources may create economic growth in figures which do not necessarily translate into widespread job creations. These facts have been observed from sub-Saharan Africa's largest oil exporter countries. In addition, large oil and mineral reserves can also distort the local currency, pushing up prices of other exports, such as agricultural products and making them much harder to sell overseas (MaryFrançoise Renard, 2011).

Overall, rich endowments of oil and metals may weaken a government's incentives for diversification and promote wasteful expenditure. Both theoretical analysis and empirical evidence show that capital-intensive natural resource abundance creates opportunities for rent-seeking behavior and that this is an important factor in determining a country's level of corruption (John Whalley and Aaron Weisbrod, 2011).

Still more, resource-rich countries often do not pursue sustainable growth strategies. They fail to recognize that if they do not reinvest their resource 
wealth into productive investments above ground, they are actually becoming poorer. Political dysfunction exacerbates the problem, as conflict over access to resource rents gives rise to corrupt and undemocratic government (John Whalley and Aaron Weisbrod, 2011).

\subsection{Nature of Chinese infrastructural interventions in the SSA}

The SSA has huge demand and deficits for new infrastructure construction and finance. According to World Bank 2009, the poor SSA electricity, water, roads and information technology- infrastructure reduces the national development by two percentage points every year and reduces productivity by as much as 40 percent. The scale infrastructures gap investment needs estimated at almost USD 93 billion a year in SSA (Akongbowa Aramwel and Andrew Oronsaye, 2010).

In this regard, Chinese first infrastructures relations with the SSA dates back to 1976, when it constructed 1860 kilometers of railway line that links Tanzania and Zambia that was meant to provide transport corridors to SSA countries. China has entered as a growing infrastructure financier in the SSA, comparable in scale to that from traditional official assistance from organization for Economic Cooperation and Development (OECD) countries or capital from private investors.

Unlike traditional official development assistance (ODA), the Infrastructure financing is channeled not through a development agency but through the export-import Bank of China. For a growing number of infrastructure loans, the EX-IM Bank is using a deal structures known as "Angol Mode" in which repayment is made in Natural resources.

One of the main objectives of Chinese investments in infrastructures in subSaharan African countries especially in those resource rich countries is getting the resources out of the country at as low a price as possible. In addition, the current infrastructures relations have grown exponentially in the last 10 years and it is commercial in nature and the focus is on infrastructures development and rehabilitation (Akongbowa Aramwel and Andrew Oronsaye ,2010). In general, Chinese finance offers an important development opportunity for subSaharan Africa, reaching a scale large enough to make a material contribution toward meeting its vast infrastructure needs. 
In general, Chinese infrastructural interventions in the SSA have the following major constraints particularly in the resource rich countries which are stated in table 4.5 below:

Table 4.5: Chinese infrastructural interventions in the SSA and its major constraints

\begin{tabular}{|c|c|}
\hline Areas & Constraints \\
\hline Qualityof infrastructural & $\begin{array}{l}\text { As far as one of the major objectives of Chinese infrastructural } \\
\text { interventions in the SSA mainly is getting the resources out of } \\
\text { the country at as low a price as possible, most of Chinese firms } \\
\text { operate with very low level of profit and they have ability to } \\
\text { undercut competitors by up to } 50 \% \text { of overall bid. This leads } \\
\text { Chinese to bring low end quality infrastructural materials from } \\
\text { China, as the result of this, most infrastructures built by Chinese } \\
\text { in SSA have lots of problems regarding qualities. }\end{array}$ \\
\hline Infrastructures market & $\begin{array}{l}\text { Because of this, Chinese ability to undercut competitors in } \\
\text { overall bid by offering low price, other competitors finding } \\
\text { themselves unable to compete with the Chinese companies. This } \\
\text { hurts the SSA ability to develop a sustainable and competitive } \\
\text { infrastructures market. }\end{array}$ \\
\hline Capacity building & $\begin{array}{l}\text { There are many critics which stated that Chinese effort to } \\
\text { support SSA human Capacity building specially infrastructure } \\
\text { areas is low. Rather majority of Chinese construction firms } \\
\text { preferred to import materials and labour directly from China. }\end{array}$ \\
\hline Corruption & $\begin{array}{l}\text { A serious constraint to this infrastructures development( } \\
\text { specially quality of infrastructures) in SSA is the issue of high } \\
\text { level of corruption of government officials that have } \\
\text { responsibility for negotiating, approving monitoring and } \\
\text { evaluating these infrastructures deals with and the willingness } \\
\text { of most Chinese construction firms to participate in these acts. }\end{array}$ \\
\hline
\end{tabular}

Source: Akongbowa Aramwel and Andrew Oronsaye (2010)

In addition to the above concerns, the rapid emergence of Chinese infrastructure financiers in sub-Saharan Africa has raised a variety of concerns among international financial institutions, non-governmental organizations and Western governments: regarding debt creation, good governance, and environmental protection (John Whalley and Aaron Weisbrod, 2011). 
Overall Chinese investments in infrastructures rehabilitation, maintenance and new construction are intensifying across the SSA. The important issues right here is SSA countries must have apriority policies, strategies as well as institutional frame works to maximize the potential benefits by reducing the risk associated with the Chinese infrastructural interventions in the SSA.

\subsection{Chinese FDI in sub-Saharan Africa, a spur for industrialization or deindustrialization?}

Currently one of the most important politically debatable questions on China's investment in sub-Saharan Africa is "Will China spur economic development or deindustrialization?" To answer this question there are opposite arguments which on one hand say, of course China is helping the development of industrialization in Sub-Saharan Africa and on the other hand, others argue the pattern of Chinese investment specially in natural resources and the cheap clothing, textiles, electronics, furniture, footwear and other import products of Chinese killing the industrial development of sub-Saharan African countries.

Those who support the idea that China is helping the development of industrialization in Sub-Saharan Africa argue by saying In 2007 the UN's annual report on the world investment stated flatly: in sub-Saharan Africa, no significant manufacturing FDI took place. Yet as the authors were writing that report, Chinese companies were actively exploring manufacturing opportunities across Africa. In 2006 World Bank survey of 477 firms of various nationalities in four countries Ghana, Senegal, Tanzania and South Africa included some data on 27 Chinese firms. Just over half of the Chinese firms were manufactures" (Deborah Brautigam ,2009).

Specially, Chinese manufactures are currently involved in sub-Saharan African countries in such areas as leather, textiles and others like cement, bricks and other building materials by establishing manufacturing zones in these countries. Many believe the growing Chinese interest in African Manufacturing acts as a counter weight to the more obvious interest in trade and natural resources.

On the other hand, others argue that even if the low prices Chinese textiles, shoes, electronic and others imports goods benefits the sub-Saharan countries consumers, it's making life very hard for domestic manufacturers. As a result

of this, records show a reduction in the average size of micro enterprises, and 
the number of SMEs (Small and Medium Enterprises) in sub-Saharan Africa. For example, African furniture exports are falling rapidly, due to competition with Chinese exports(C h r i s A $1 \mathrm{~d}$ e $\mathrm{n}$ a $\mathrm{nd} \mathrm{A} \mathrm{n} \mathrm{a} \mathrm{C} \mathrm{ris} \mathrm{t} \mathrm{in} \mathrm{a} \mathrm{A} \mathrm{l} \mathrm{ve} \mathrm{s,}$ 2009).

In line with these, some also argue as far as Chinese firms may have relatively weak linkages with local firms, so their contributions for the development of local industries are very low (John Whalley and Aaron Weisbrod, 2011). Besides this, others also indicate that China's huge FDI in sub-Saharan African natural resources can be causes of Dutch disease. As a consequence, natural resource economies will tend to have larger service sectors and smaller manufacturing sectors than resource-poor economies. In this regard, Chinainduced negative terms of trade shock will cause a contraction of the tradable sector coupled with an adverse effect on the non tradables sector. In sum, the impact of China on Sub-Saharan economies will depend critically on the country's factor endowments (John Whalley and Aaron Weisbrod, 2011).

\subsection{Costs and Benefits of Sino FDI in Ethiopia: Trend and impact of Chinese FDI in the Ethiopian Economy}

The impact of China on African economies particularly in sub-Saharan Africa has been diverse, depending in part on the sectoral composition of each country's production. Ethiopia is no exception to this impact.

The economic linkages between China and Ethiopia have been strengthened through both trade and Chinese direct investment in Ethiopia for the past decades. In the last 7 years China has become an important trading partner of Ethiopia accounting to about $15 \%$ of its trade which was none before 2005 (Alemayehu Geda and Atnafu G. Meskel,2010).

According to the Ethiopian Investment Agency (EIA) which is the only legal government entity that licenses domestic and foreign investment activity in Ethiopia, from 1998-2012 a total 948 Chinese businesses got licenses to invest in Ethiopia. Out of these numbers $10 \%$ of them are under implementation phase, $33 \%$ are operational and 57\% are under pre- implementation stage. The cumulative investment capital of Chinese owned investment from 1998-2012 reached 41,663,744,000 birr $(2,314,652,444$ USD). What makes the China FDI in Ethiopia unique is that $60 \%$ of these investments are concentrated in the manufacturing sector which is different from what happened in other African 
countries where the Chinese FDI is pretty much resource seeking. Table 4.7 below is the Summary of Licensed Chinese investment Projects by Sector and status since August 27, 1998 to December 19, 2012.

\section{Table 4.7: Chinese Investment Projects in Ethiopia (1998-2012)}

Summary of Licensed Chinese Investment Projects By Sector and Status Since August 27, 1998 to December 19, 2012

\begin{tabular}{|c|c|c|c|c|c|c|c|}
\hline Sector & $\begin{array}{l}\text { No. } \\
\text { of } \\
\text { Proj. }\end{array}$ & $\begin{array}{l}\text { Capital in } \\
\text { "000" Birr }\end{array}$ & $\begin{array}{l}\text { Per.Em } \\
\text { p }\end{array}$ & $\begin{array}{l}\text { Temp.E } \\
\text { mp }\end{array}$ & $\begin{array}{l}\% \\
\text { Implementat } \\
\text { ion }\end{array}$ & $\begin{array}{l}\% \\
\text { Operatio } \\
\mathrm{n}\end{array}$ & $\begin{array}{l}\text { \% pre- } \\
\text { Implementati } \\
\text { on }\end{array}$ \\
\hline Agriculture & 32 & $4,022,596$ & 1,500 & 4,784 & $9.3 \%$ & $6.2 \%$ & $84.4 \%$ \\
\hline $\begin{array}{l}\text { Mining and } \\
\text { quarrying }\end{array}$ & 10 & 174,238 & 463 & 1,355 & $10 \%$ & $20 \%$ & $70 \%$ \\
\hline $\begin{array}{l}\text { Manufacturi } \\
\text { ng }\end{array}$ & 542 & $30,303,683$ & 45,081 & 34,449 & $12.5 \%$ & $34.5 \%$ & $53 \%$ \\
\hline Education & 3 & 2,430 & 18 & 11 & $33.3 \%$ & $33.3 \%$ & $33.3 \%$ \\
\hline Health & 13 & 29,868 & 86 & 81 & $0 \%$ & $61.5 \%$ & $38.5 \%$ \\
\hline $\begin{array}{l}\text { Hotels } \\
\text { (Includng } \\
\text { Resort } \\
\text { Hotels,Motels } \\
\text { and } \\
\text { Lodges)and } \\
\text { Resaurants } \\
\end{array}$ & 68 & 579,145 & 2,153 & 893 & $4.4 \%$ & $22.1 \%$ & $73.5 \%$ \\
\hline $\begin{array}{l}\text { Tour } \\
\text { Operation, } \\
\text { Transport, } \\
\text { storage and } \\
\text { communicati } \\
\text { on }\end{array}$ & 12 & 21,774 & 302 & 230 & $17 \%$ & $25 \%$ & $58 \%$ \\
\hline $\begin{array}{l}\text { Real estate, } \\
\text { Machinery } \\
\text { and } \\
\text { Equipment } \\
\text { Rental and } \\
\text { Consultancy } \\
\text { Service }\end{array}$ & 150 & $1,851,744$ & 7,188 & 9,250 & $3 \%$ & $38 \%$ & $59 \%$ \\
\hline $\begin{array}{l}\text { Construction } \\
\text { Contracting } \\
\text { Including } \\
\text { Water Well } \\
\text { Drilling }\end{array}$ & 112 & $4,619,166$ & 10,251 & 28,119 & $13.4 \%$ & $31.3 \%$ & $55.4 \%$ \\
\hline Others & 6 & 59,100 & 86 & 295 & $0 \%$ & $33.3 \%$ & $67 \%$ \\
\hline Total & 948 & $41,663,744$ & 67,128 & 79,467 & & & \\
\hline
\end{tabular}

Source: Ethiopian Investment Agency and author's compilation 
Table 4.7 indicates that Chinese investment projects in Ethiopia (1998-2012) were expected to generate 67,128 permanent and 79,462 temporary employment opportunities. In addition, out of these Chinese investment projects, the number of projects in education, health and Mining and quarrying is very low compared to other projects such as manufacturing, construction, and hotels. when we see the Status of these projects specially the health projects almost $61.5 \%$ of them are operational, in $34.5 \%$ of project manufacturing are operational, education, and real estate, machinery and equipment rental and consultancy Service respectively, 33.3\% and 38\% are operational and the low operational status among these projects is the Agriculture sector which is only $6 \%$ is operational.

According to the interview response result of this study with Ethiopian Investment Agency officials, one of the major problems of these Chinese investment projects in Ethiopia is, the majority of these projects are not active enough to be operational within short period of time. As a result of this, the Agency canceled 677 of Chinese investment projects licenses given from August 27, 1998 to December 19, 2012 (or $71.4 \%$ of licensed Chinese investment projects Since August 27, 1998 to December 19, 2012) because these investments did not start their activities within six months based on the Ethiopian investment law proclamation. Even some of these Chinese firms have been found operating in an activity other than for which they were granted investment license. One of the causes of this problem can be the ineffective monitoring and evaluation systems of the Agency investments projects. In this respect according to the interview response with Ethiopian Ministry of Trade officials, once Chinese investors got the right to import merchandise products as domestic Ethiopian importers, instead of investing in Ethiopia based on their granted investment license, some of them were involved in import business to realize short term profit.

In general, to find out why Chinese investment projects are very slow to operate in Ethiopia it needs further additional researches. Table 4.8 provides the Summary of Cancelled Chinese Investment Projects August 27, 1998 to December 19, 2012. 
Analysis of Chinese FDI in Sub-Saharan Africa

Table 4.8: List of Cancelled Chinese Investment Projects August 27, 1998 to December 19, 2012

\begin{tabular}{|l|l|l|}
\hline Sector & No. Canceled projects & $\begin{array}{l}\text { \% out of the total } \\
\text { cancelled } \\
\text { investment projects }\end{array}$ \\
\hline Agriculture & 47 & 7 \\
\hline Manufacturing & 380 & 57 \\
\hline $\begin{array}{l}\text { Service(hospital, Hotels, } \\
\text { education, consultancy } \\
\text { service and other) }\end{array}$ & 150 & 22 \\
\hline Construction & 100 & 15 \\
\hline Total & 677 & \\
\hline Source: Ethinese
\end{tabular}

Source: Ethiopian Investment Agency and author's compilation

Table 4.8 indicates among the total cancelled Chinese investment projects from August 27, 1998 to December 19, 2012, majority of them are manufacturing investment projects. The two major reasons why these manufacturing investment projects could not start in the specified time and subject to cancelation could be, according to the interview response with Ethiopian Investment Agency, Ministry of Industry, Ministry of Trade, Ethiopian Conformity and Assessment Enterprise:

$\checkmark$ Because this sector might not be profitable for them;

$\checkmark$ Because the Ethiopian government environmental and labor policy is very strict for manufacturing sector.

\subsection{Values of China infrastructure interventions in Ethiopia}

Chinese firms are engaged highly in Ethiopian infrastructural development including road, telecommunication, power and railway projects. In addition Chinese Development AID has played a huge part in these infrastructural projects in Ethiopia. Currently, for example, Ethiopian officials have succeeded in winding up a deal with their counterparts in China that involves 1.4 billion dollars in loans, which will be used to finance the national railway project. This loan is the largest loan amount for Ethiopia to get from a bilateral source and will raise the nation's debt for national railway project to 6.21

EJBE Vol. 4 No. 2/2014

Page 207 
billion dollars, comprising $16 \%$ of its gross domestic product (GDP) projected for the year 2012/2013) Addis Fortune, Vol. 13, No. 641 ,2012).

In the power sector, the Chinese engagement is growing in Ethiopia. Currently, the value of the power generation in which the Chinese companies involved is estimated at about more than 1.7 billion US. Similarly, Chinese firms are dominating in winning big projects in Ethiopian telecommunication. One of the biggest Chinese telecom company, ZTE, which is owned by the Chinese government has offered the Ethiopian telecom a credit (vendor financing) to the tune of 1.5 billion USD. This offer is conditional on ZTE doing the job without bidding. This credit is perhaps equivalent to the total current worth of the Ethiopian telecom monopoly, which is also publicly owned (Alemayehu Geda and Atnafu G. Meskel, 2010).

Of course, Chinese investment especially in the telecom sector is helping Ethiopia a lot but according to the interview response with telecom experts who are working for the company they expressed their fear regarding the poor quality of network system and the high operational cost especially spare parts cost of this ZTE Company.

Chinese firms are also dominating both rural and urban road construction in Ethiopia. At present for example, out of 18 huge road projects constructed by foreign companies in Ethiopia $78 \%$ are accounted by Chinese firms. These Chinese firms owned projects contract amount is 24,179,300,000 billion birr $(1,343,294,444$ Billion USD) (Ethiopian Road Authority Planning Department data base, 2013). In road infrastructure development, Ethiopia is the most successful in making progress. Behind this good progress there is no question that Chinese firms are there.

According to the interview response with Ethiopian Road Authority officials, these Chinese firms are selected through their low bid offer and their fulfillment of technical standards (including quality). In addition, in some cases, these firms came with vendor financing. On the other hand, this study has used unstructured interview with Engineers who are working in construction sector in Ethiopia. Some raised concerns regarding the poor qualities of Chinese firms' construction works in Ethiopia but according to the findings of this study, there is no tangible evidence that proves these concerns. But some raised concerns patient to the all qualities checking works outsourced by Ethiopian Road Authority to external consultants firms. If there is some 
collision between the consulting firms and the Chinese construction in order to compromise qualities set by the Authority, there is no means to cross check these works.

Regarding the roles of Chinese firms' in capacity building and technology transfer in the construction sector in Ethiopia, the interview response with Ethiopian Road Authority officials and some Ethiopian engineers working with Chinese construction firms is not encouraging. The interview responses on these poor activities of Chinese firms in capacity building and technology in construction in Ethiopia cited the following reasons:

1. Ethiopian Roads Authority has no clear policies and strategies on how the Authority works with these Chinese firms in capacity building and technology transfers. In some ways Ethiopian Road Authority seems to forget the future skilled man power requirements regarding maintenance, upgrading of Roads etc;

2. Capacity building of Ethiopian professionals through activities such as training, is not set by Ethiopian Road Authority as a prior requirement in bids companies;

3. Some Chinese construction firms are not interested to work with Ethiopian professionals. This study took a South Korean construction company working in Ethiopia (Keangnam) to compare with Chinese construction firms in professional staff compositions. The result shows that $3 / 4$ of South Korean construction company professionals are Ethiopians, so this creates an opportunity for Ethiopians to upgrade their skills by working with them .On the other hand, most Chinese firms only hired unskilled labor;

4. Language barriers: most Chinese engineers who are working in Ethiopia cannot speak English or the national language "Amharic " so it creates its own problems in skill transfer.

\subsection{Impacts of Chinese leather and textile imports on Ethiopian Leather and Textile Manufactures}

The study secured the response of seven Ethiopian leather manufactures and six Ethiopian textiles manufactures owners and managers using telephone interview. The result shows in general, Chinese leather and textile imports 
have serious negative impact on Ethiopian leather and textile Manufactures profitability and market share. As one can observe from table 4.9 below, $100 \%$ of the respondents stated that Chinese leather and textile imports have serious negative impact on the domestic leather and textile manufactures profitability and market share.

According to these respondents, the causes of these problems are most Chinese products are of very low quality and are available in the market with low price; so domestic customers got swayed to buy to these products very easily. In addition, the Ethiopian Conformity Assessment Enterprise's inability to conduct an effective and thorough assessment on suits standard products of Chinese companies has enabled such products to gain easy access in to the local market. The fact that the price of such products is very low in comparison to local products of much better qualities is severely harming market share of local manufactures.

Table 4.9 Summary of responses on the Impacts of Chinese leather and textile imports onEthiopian leather and textile manufactures

\begin{tabular}{|l|l|l|l|l|}
\hline Enquiry & \multicolumn{3}{|c|}{ Response } & \\
$\begin{array}{l}\text { Do the } \\
\text { imported } \\
\text { textiles(or } \\
\text { Leather) } \\
\text { products harm } \\
\text { your company }\end{array}$ & Yes: 100\% & NO: & \\
\hline $\begin{array}{l}\text { If your answer } \\
\text { for the above } \\
\text { question is } \\
\text { "yes "what are } \\
\text { the impacts? }\end{array}$ & $\begin{array}{l}\text { profitability: } \\
100 \%\end{array}$ & $\begin{array}{l}\text { In terms of } \\
\text { market } \\
\text { share :100\% }\end{array}$ & $\begin{array}{l}\text { Make your } \\
\text { business out the market } \\
\text { of } \\
0 \%\end{array}$ & $\begin{array}{l}\text { Any other } \\
\text { reasons: 0\% }\end{array}$ \\
\hline
\end{tabular}

4.10 Roles of China's investment for capacity building and technology transfer in Ethiopia

One of the significant contributions of China in capacity building and technology transfer in Ethiopia is the financing of vocational training centers. 
In Ethiopia, a larger training and vocational education center financed by Chinese aid and jointly operated by the two countries opened in early 2009 . This school has a capacity to enroll 3000 students and giving short term trainings in the areas of construction, electronics, textiles, and computers, etc( Deborah Brautigam ,2009). In addition some Ethiopians are also getting scholarships in China's Universities including Children of local politicians.

For the purpose of this study, survey was conducted on Ethiopian employees who are working for Chinese Eastern Industrial zone, Dukem City Administration in Ethiopia. In this Industrial zone currently, three companies are operational. These companies are Great Wall Packing Material PLC, Hua Jian International Shoe City PLC and Jhun Hug Cement Factory. At the time of the survey in this Zone more than 2500 employees were working. 300 employees were asked by using self administered interview questionnaire using random sampling selection to find out whether they were getting training or any other capacity building on the area of their activities, $96 \%$ of them responded they got appropriate training before they started the job and on the job training also. Specially Hua Jian International Shoe City PLC trained many Ethiopian employees locally and by taking them to China for short and long term training. In addition because of these Chinese companies' investments, new technologies are introduced for Ethiopian firms which are engaging in the same industrial sector.

However, one of the problems currently Ethiopia is facing is that as a country there are no clear policies and strategies that help to maximize capacity building and technology transfer from Chinese and other foreign FDI investments. In general few of China's investments in Ethiopia as stated above, have a good start for capacity building and technology transfer in Ethiopia

\subsection{Is China investment making corruption worse in Ethiopia?}

Because China is supporting undemocratic regimes, concerns are growing about its contribution to the development of governance in African countries. However, China's critics ignore the root cause of why many African leaders are corrupt and unaccountable to their population. In line with this, it is very difficult to conclude that the Chinese have worsened corruption in Africa because they have partnered with Mauritius, South Africa and Botswana which 
are best governed countries. On the other hand, China has also partnered with Angola, Equatorial Guinea and the Democratic Republic of Congo, countries regarded as some of Africa's most corrupt (John Whalley and Aaron Weisbrod, 2011).

Of course, researching corruption is very difficult. According to Transparency International, there is a concern on corruption related with Chinese activities in Africa. But this concern is not based on hard data; rather rely on perception of corruption. These concerns rely on two major assumptions. First, huge new sums of money from China might be tempting targets for embezzlement. Second, Chinese firms with looser attitudes about corruption might cheat, winning contracts away from more honest companies (John Whalley and Aaron Weisbrod, 2011).

In this regard, there are so many concerns with the Chinese firms' investment activities in Ethiopia. But all the concerns are not based on hard data. According to the interview response with Ethiopian Ethics and Anti Corruption Commission officials, there are only three cases presented related with Chinese investors to court regarding corruption since the establishment of the Commission. But as per these officials there are some concerns of corruption around the construction sector in relation to Chinese firms in Ethiopia.

According to Ethiopian Revenues and Customs Authority Investigation Directorate data base from 2008-2012 around 20 Chinese investors have been sued in court by the Authority because of contraband, tax evasion, trade fraud, capital flight, money laundrying and illegal transfer of wild animal skin. In addition according to the interview response there are also concerns on some Chinese Companies regarding tax evasion patient to employment tax and income tax.

In general, from the above facts even if it is difficult to conclud that China investment as a factor for worsening corruption in Ethiopia, there are some indications that should seriously be considered by the Ethiopian government before the problem gets much more aggravated.

\subsection{China FDI and environment issue in Ethiopia}

China's modernization efforts not only feature a heavy industrial structure and a fast-growing auto industry but have caused severe damage to China's 
environment and the overall ecosystem, and in the process have made China one of the worst polluters on earth (Wenran Jiang, 2009).

In this regard, as far as China's FDI in Ethiopia is concerned almost $60 \%$ of these investments are concentrated in the manufacturing sector, which is different from what happened in other African countries where the Chinese FDI is pretty much resource seeking. Accordingly there are so many concerns in relation to the level of environmental damage of these industries.

According to the Ethiopian Ministry of Industries, the types of Chinese manufacturing industries currently operating in Ethiopia mainly are Cement factories, metal and plastic factories, textile factories, Glass factories, steel factories, Chemical factories and car assembling factories. Out of these factories some of them are highly populated. It was found out through interviewing Ethiopian Conformity Assessment Enterprise officials that if there are no many problems regarding Chinese manufacturing industries on environment issues in Ethiopia. However problems have been observed in one Glass factory to the effect that it was closed by the Enterprise. The other problem which has been observed was the Chinese attitude toward environmental issues is not very serious. This has resulted in misunderstanding with this Enterprise during Environmental assessment. In addition, the problems that are currently faced by Ethiopian Conformity Assessment Enterprise with Chinese manufacturing companies reveal that some of the machineries that are used by these factories are old hence their sensitivity to the environment is in question.

As a final note, as China's FDI are concentrated in the manufacturing sector in Ethiopia, the possibility of environment and the overall ecosystem damage will be there unless the government of Ethiopia monitoring and evaluation capacity to follow up such industries is upgraded time to time.

\subsection{Chinese Manufacturing Companies' employees safety in Ethiopia}

In this study survey it was managed to get the response of 200 employees who are working in Chinese Eastern Industrial Zone, Dukem City Administration in Ethiopia and Dukem Labour and Social Affairs Agency labour inspector using self administered interview questionnaire. In addition as a secondary data this study used the official assessment letter written by Dukem Zone Labour and 
Social Affairs Agency regarding employee safety for the two companies ${ }^{2}$, which are found in Eastern Industrial Zone.

The result shows that $96 \%$ of the employees responded that Chinese companies are not worried much for safety at work places. In addition according to their response some of the Chinese managers are autocratic so they simply want to fire them from their jobs without sufficient reason. Even though the majority of employees in the Chinese firms under study claimed their wages were "unfair" their wage levels are found to be higher than the average in local firms..

In line with the above complaints of employees, the official assessment letter written by Dukem Zone Labour and Social Affairs Agency regarding employee safety for companies, which are found in this Eastern Industrial zone, stressed the following points as weaknesses of these companies on employee safety:

1. the companies do not have health and personal safety standard;

2. there are no warning signs and safety rules in the working place;

3. there is no medical examination taken for those workers engaged in hazardous work ;

4. no training programs concerning the prevention of employment injuries ;

5. There is no provision of personal protective equipment and employees do not use personal protective equipment properly and have low awareness

6. There is no schedule for annual leave;

7. There are no first aid box in production areas;

\footnotetext{
${ }^{2}$ The companies are Great W all Packing M aterial PLC and Hua Jian International Shoe City(Ethiopian) P.L.C
} 
8. There are no enough toilets and not separated for female and male ;

9. There is forced assignment of employees on overtime without their willingness;

10. There are no documented employees' personal files.

According to the interview with Dukem Labour and Social Affairs Agency labour inspector, these Chinese companies are not willing to work with government offices on safety issues instead they frighten them by saying they would go to the higher government offices if the inspectors created a problem upon them .

As a final note, these reluctant attitudes of Chinese manufacturing companies not to care for employees safety in Ethiopia is reflected not only in Eastern industrial zone but also in other Chinese companies which are found in Ethiopia too. One of the major causes for this problem according to the findings of this study is the Ethiopian Government's weak positions to take serious measures against these companies.

\section{Conclusions and Policy Recommendations}

\subsection{Conclusions}

The purpose of this study was to explore and identify the Chinese Foreign Direct Investment (FDI) in Sub - Saharan Africa: A Particular Focus on Ethiopia. The analysis of the study indicated that following the extraordinary economic growth of China, currently the Chinese appetite for the African's energy, natural resources and market for cheap Chinese products has dramatically increased. In this regard the Chinese FDI in sub-Saharan Africa countries especially in those resource rich countries has shown significant growth. As a result, Chinese FDI in Sub-Saharan Africa has several advantages and disadvantages. The major advantage is that China has certainly been contributing to sub-Saharan Africa's economic growth, both in terms of trade and with building of infrastructure.

However, the Chinese exports of natural resources by themselves do not help sub-Saharan Africa because oil and mining are not labor intensive industries; 
so even if natural resources may create economic growth in figures, not necessarily translate into widespread job creations. These facts have been observed from sub-Saharan Africa's largest oil exporter countries. In addition, large oil and mineral reserves can also distort the local currency, pushing up prices of other exports; such as agricultural and manufacturing products making them much harder to sell overseas.

Regarding the costs and benefits of Sino FDI in Ethiopia, it was stated that in the last 7 years, China has become an important trading partner for Ethiopia accounting to about $15 \%$ of its trade which was none before 2005 . What makes the China FDI in Ethiopia unique is that almost $60 \%$ of these investments are concentrated in the manufacturing sector which is different from what happened in other African countries where the Chinese FDI is pretty much resource seeking.

The major benefits of China FDI in Ethiopia are Chinese firms are highly engaged in Ethiopian infrastructural development including road, telecommunication, power and railway projects. In addition, the Chinese investment projects currently are generating foreign currency (export) and employments for local peoples. But there are concerns related to China FDI in Ethiopia such as dumping of low quality Chinese goods in Ethiopian markets, Chinese manufacture poor employees' safety, the Chinese imports negative impact on domestic industries and Chinese investors' involvements in corruption and other trade frauds

\subsection{Policy Recommendations}

The Chinese businesses coming to sub-Saharan Africa including Ethiopia, are diversifying the relationship away from simply government- to government relationships. The major problem that sub-Saharan African countries currently facing is that they have no appropriate policies and strategies including strong institutional arrangement to maximize benefits from these China FDI by minimizing the risks associated with the investments.

In view of the above, a number of policy recommendations can be suggested to maximize the benefits and to limit the negative effects on China FDI in subSaharan Africa particularly in Ethiopia. In general those resource rich subSaharan African countries must put in place the institutions, policies, and laws needed to ensure that the resources benefit all their citizens. In addition, to 
benefit from these Chinese large flows of FDI in the region, the countries should not be allowed to delay much needed domestic reforms, such as strengthening economic management and improving the business environment. Particularly in Ethiopia, the government must implement appropriate policies and strategies including institutional arrangements to maximize benefits from these Chinese large flows of FDI regarding:

- Capacity building and technology transfer from Chinese firms;

- Creating supply chain for domestic manufactures with Chinese firms;

- boost the country's export from these Chinese manufacturing firms exports by reducing their negative impact on environment and employment safety;

- upgrading the country's infrastructures from these Chinese firms investment by taking seriously the quality of the work of these firms into account;

Overall, the study has shown that it requires further studies to give a detailed recommendation of what types of policies and strategies sub-Saharan Africa should adopt to maximize benefits by minimizing risks from Chinese FDI. 


\section{References}

Aramwel, A. and Oronsaye, A. (2010). Rethinking Sub Sahara Africa (Ssa)China Infrastructures Development Cooperation For Sustainable Economic Development And Growth: Issues, Prospects And Challenges. The Renaissance of African economies Dar es salam, Tanzania, 20 - 21 / 12 / 2010.

Bevan, A.A and Estrin, S. (2000). The Determinants of Foreign Direct Investment in Transition Economies. Centre for New and Emerging Markets, London Business School. William Davidson Institute Working Paper 342.

Geda, A. and Meskel, A.M (2009)." Impact of China-Africa Investment Relations: Case Study of Ethiopia”. African Economic Research Consortium. AERC, Nairobi.

Zafar, A. (2007). "The Growing Relationship between China and Sub-Saharan Africa: Macroeconomic, Trade, Investment, and Aid Links". The World Bank Research Observer, vol. 22, no. 1 (Spring 2007).

Desta, A. (2009). Chinese Investment in Ethiopia: Developmental Opportunity or Deepening China's New Mercantilism? Retrieved on 22oct.2012from

http://aigaforum.com/articles/Chinese_Investment_in_Ethiopia_052009.htm. Žilinske, A. (2010). Negative and positive effects of foreign direct investment. ISSN 1822-6515 Economics and Management: 2010. 15. Kaunas University of Technology.

Chen, C., Pushak, N., Butterfield, W. and Foster, V. (2009). Building Bridges:China's Growing Role as Infrastructure Financier for Sub-Saharan Africa. Building Bridges-Executive Summary.World Bank.

Aldenand, C. and Alves, C. (2009). China and Africa's Natural Resources: The Challenges and Implications for Development and Governance. South African Institute of International Affairs.

Brautigam, D (2009). The Dragon's Gift: The Real Story of China in Africa. United States by Oxford University Press Inc..., New York .

Walsh, J.P and Yu, J. (2010). Determinants of Foreign Direct Investment: A Sectoral and Institutional Approach. IMF Working Paper (WP/10/187) Asia Pacific Department. 
Anyanwu, J.C (2012). Why does foreign direct investment go where it goes?: New evidence from African countries. Annals of economics and finance 13-2, $433\{470$ (2012).

Whalley, J. and Weisbrod, A. (2011)." The contribution of Chinese FDI to Africa's pre-crisis growth surge. Retrieved on oct.1, from http://www.voxeu.org/article/contribution-chinese-fdi-africa-s-growth.

Stiglitz, J. "Resource Blessing Possible, Not Easy" Addis Fortune, Vol. 13, No. 641 (2012).

Madukwe, M.C (2006). The impact of Chinese investment in African Economies, a personal view. Department of Agricultural Extension University of Nigeria, Nsukka Nigeria.

Vong, L.K (2005). Foreign Direct Investment: Concepts and Relevance to Macao. Research and Statistics Department, Monetary Authority of Macao.

Houanye, P. (2012). Foreign Direct investment in Africa: securing Chinese's investment for a lasting development in Africa. Global Conference on Business and Finance Proceedings $\$$ Volume 7 Number 1, 2012.

Bosshard, P. (2007). China's Role in Financing African Infrastructure. International Rivers Network.

Renard, M. (2011), China's Trade and FDI in Africa, Series $\mathrm{N}^{\circ} 126$, African Development Bank, Tunis, Tunisia. The African executive" why China Will Not Solve Africa's Problems" The Daily Monitor, Monday,August 13.

Jiang, W. (2009). Fuelling the Dragon: China's Rise and Its Energy and Resources Extraction in Africa. The China Quarterly. 